\title{
D. Inácio de Santa Teresa e o Movimento Jacobeu
}

\author{
José Maria Mendes ${ }^{1}$
}

\section{Submetido em \\ Aceite em}

$14 / 12 / 2016$

$11 / 2 / 2017$

Resumo: Enquanto arcebispo de Goa, D. Inácio de Santa Teresa foi acusado de jansenista e jacobeu pelos Jesuítas. E, com base na afirmação de que "as boas obras em pecado são abominação para Deus", proferida num sermão da semana santa, foi denunciado ao Tribunal do Santo Ofício. Considerou-se inocente da acusação que lhe foi feita e acabou por ver a sua inocência reconhecida pelo Papa. 0 que foi afinal o Jansenismo? Na sequência da Reforma de Lutero, assistiu-se ao surgimento de movimentos que, de uma ou de outra forma, advogavam o retorno da Igreja à sua pureza original. Um deles foi justamente o Jansenismo que em Portugal se confundiu com a Jacobeia. Procurou-se no texto, assinalar as origens deste movimento religioso de modo a contextualizar-se a sua presença em Portugal. D. Inácio de Santa Teresa foi um dos pilares desse movimento, que integrou um grupo de figuras gradas da Igreja e que acabou por enredar-se num conflito de consequências demolidoras. Esse conflito teve duas vertentes distintas: A primeira parte, que vai até 1748 , tem como motivo essencial, uma disputa teológica, que se desvanece com uma intervenção papal; a segunda assume características políticas em que se destacam as figuras do Marquês de Pombal e de D. Miguel da Anunciação, bispo de Coimbra, e que teve consequências trágicas.

Palavras Chave: Inácio de Santa Teresa, Jacobeia, Jacobeia, Miguel da Anunciação, Marquês de Pombal.

Abstract: As archbishop of Goa, Dom Inácio de Santa Teresa was accused by Jesuits to be a jansenist and a jacobeian. Based upon the statement that "good works in sin are an abomination before God," attributed to him in a sermon of the holy week, he was denounced to the Tribunal of the Holy Office. He considered himself innocent of the accusation and had his innocence recognized by the Pope. What was Jansenism? Following the Lutheran Reformation, there were movements that, in one way or another, advocated the return of the Church to its original purity. One of them was Jansenism, which in Portugal was confused with Jacobeia. It is sought in this article, to trace the origins of this religious movement in order to contextualize its presence in Portugal. D. Inácio de Santa Teresa was one of the pillars of this movement, a prominent figure in the Portuguese Church. He became entangled in a conflict that shook the structures of this institution. This conflict had two distinct strands: The first goes until 1748, as a theological dispute, which faded with a papal intervention; The second took on political colours with tragic consequeces, and saw the involvement of the Marquis of Pombal and D. Miguel da Anunciação, Bishop of Coimbra.

Key-words: Inácio de Santa Teresa, Jacobeia, Jansenism, Miguel da Anunciação, Marquês de Pombal

1 Licenciado em História pela Universidade Lusófona, em 2009. Prosseguiu os estudos na Faculdade de Letras da Universidade de Lisboa, onde concluiu, em 2012, o mestrado em História dos Descobrimentos e da Expansão, e, em 2015, o doutoramento na mesma área. Investigador associado do CPES-Centro de Pesquisa e Estudos Sociais da Universidade Lusófona e investigador integrado do Centro de História da Faculdade de Letras da Universidade de Lisboa. 


\section{Introdução}

D. Inácio de Santa Teresa, Cónego Regrante de S. Agostinho, ascendeu aos Estudos Maiores no Colégio de Coimbra, em cuja Universidade obteve o grau de doutor em Teologia, prosseguindo ali a sua carreira como professor de Filosofia, Teologia e Moral.

Em 22 de novembro de 1720, D. João V optou por D. Inácio de Santa Teresa, então com 38 anos de idade, para exercer o cargo de arcebispo de Goa, tendo assumido funções a 25 de setembro do ano seguinte.

Em Goa foi acusado de práticas jansenistas, o que the valeu a instauração de um processo pelo Tribunal do Santo Ofício, apesar do alto cargo que exercia. Defendeu-se intransigentemente da acusação, acabando por ver reconhecida a sua inocência por Bento XIV.

Mais tarde, quando já bispo do Algarve, foi um dos pilares do grupo que integrou figuras gradas da Igreja e que acabou por enredar-se num conflito, que veio a ser conhecido pela Questão do Sigilismo, que abalou as estruturas dessa Instituição. Esse conflito teve duas vertentes distintas: A primeira, que vai até 1748 , pode considerar-se, claramente, uma disputa de caráter teológico, que se desvaneceu com uma intervenção papal; a segunda assume características políticas em que se destacam as figuras do Marquês de Pombal e de D. Miguel da Anunciação, bispo de Coimbra, e que teve consequências trágicas.

Da historiografia existente sobre o tema versado destaca-se um conjunto de textos avulsos, alguns deles de apreciável valor, sobretudo para o estudo da segunda fase do conflito que envolveu o Marquês de Pombal, D. Miguel da Anunciação e os restantes Jacobeus, estudos que melhor se identificam na Bibliografia.

Luís Cabral de Moncada, no fascículo, que tem o título de Uma página de História Religiosa Portuguesa no Século XVIII: "Jacobeus" e "sigilistas", ocupa-se com a chamada questão do sigilismo, com a mestria que the era peculiar.

Fortunato de Almeida, na História da Igreja em Portugal (1 ${ }^{\text {a }}$ ed., 1910-1921), aflora, com alguma particularidade, a questão dos jacobeus e do sigilismo.

São ainda de assinalar os estudos dos seguintes autores:

Perrone, Nicolas Hernán, "Si no eres jesuita serás jansenista; y si no eres jansenista serás jesuita. El problema del jansenismo en causas de la revolución de Francia de Lorenzo Hervás Y Panduros S.J. (1735-1809)". 
Manuel Augusto Rodrigues, D. Miguel da Anunciação e o Cabido da Sé de Coimbra. Emile Appolis, Mystiques portugais du XVIIle siècle : jacobéens et sigillistes.

No que diz respeito a obras de maior fôlego, devem anotar-se a de Fr. António Pereira da Silva intitulada A questão do sigilismo em Portugal no século XVIII: história, religião e política nos reinados de Dom João $V$ e de Dom José, porventura o estudo mais completo; O trabalho de Everton Sales Souza, Jansénisme et Reforme de l'Église dans l'empire portugais que, para além da contenda do sigilismo, examina o processo em que o Arcebispo foi acusado de jansenista pelo Santo Ofício, o mesmo sucedendo com Ronaldo Vainfas e outros, na obra A Inquisição em xeque: temas, controvérsias, estudos de caso.

\section{Jansenismo: De Baio a Quesnel}

Após a Reforma Protestante, no começo do séc. XVI, assistiu-se ao nascimento de um conjunto de movimentos que propunham as mais díspares soluções para o retorno da Igreja à sua pureza original na tentativa de minimizar os efeitos perversos das teses luteranas.

Martinho Lutero (1483-1546), frade dos eremitas de Santo Agostinho, encontrou na Epístola de S. Paulo aos Romanos, onde o apóstolo declarou que “O justo viverá pela fé”. I, 17), justificação para as dúvidas que o afrontavam a respeito da salvação. Dessa afirmação extraiu o entendimento de que o homem poderia salvar-se, não por aquilo que fizesse, não pelas obras boas ou más que praticasse, mas pela sua fé, pela confiança na morte de Cristo narrada pelo Evangelho ${ }^{2}$.

Lutero, na linha de Santo Agostinho, embora não tenha levado a questão do pecado original ao extremismo assumido por este, parte de uma avaliação pessimista da natureza humana, manchada pelo pecado original, para negar ao homem, nascido pecador, a possibilidade da salvação através das obras que praticasse, abrindo, como única porta para a salvação, o sacrifício de Cristo. O homem tornava-se consciente desse sacrifício através da fé. Deus concedia gratuitamente ao homem a graça da fé e da salvação.

Entendendo assim, com a doutrina da justificação pela fé firmada no Evangelho, Lutero não limitava a sua ação a uma simples discussão contra os abusos da Igreja de Roma e do papado. A sua atuação questionava, mais do que tudo, a própria essência da doutrina dessa Igreja, propondo novas doutrinas e formas diferentes

2 R. D. Pizzinga, Pensamentos de Lutero, Um revolucionário religioso, disponível em http://ordoilluminatorum. net/, consultado em 17 de Março de 2016. 
de compreender a experiência religiosa adotada até então. No fundo, tratava-se de uma proposta de criação de uma igreja invisível simplesmente constituída pela comunidade de fiéis, em suma, uma igreja nova.

$\mathrm{Na}$ verdade, esta doutrina de Lutero, a doutrina da justificação, colocava em causa todo o mecanismo de salvação da Igreja católica, negando todas as suas práticas como os votos dos monges e frades, as penitências, a Virgem e os santos, a prática das indulgências e a própria existência do purgatório, como meios de alcançar a salvação.

A polémica conduziu a uma total rutura da unidade cristã, mantida durante séculos. Estava, assim, implementada a reforma protestante que gerou, por toda a Europa, um sem número de movimentos redentores, no seio da própria Igreja Católica. Um deles, o Jansenismo, nascido em França, por iniciativa de Miguel Baio, ${ }^{3}$ desencadeou uma agitação por ela poucas vezes experimentada.

Baio, nascido em Mélin, Hainaut, na Bélgica, em 1513, fez os seus estudos na Universidade de Lovaina, evidenciando, desde cedo, uma preferência pelas ciências filosóficas e teológicas.

Em 1550, doutorou-se em Teologia, tendo-lhe sido entregue a cadeira de Sagrada Escritura. A posição superior a que se alcandorara criou-lhe o ambiente propício para a difusão das doutrinas controversas que partilhava com João Hessels, docente da mesma Universidade.

Michel Baio considerava que o homem ficara de tal modo corrompido pelo pecado original, que somente a graça eficaz e irresistível poderia levá-lo à prática do bem. Tal como Lutero, Baio colheu inspiração na doutrina de Santo Agostinho, numa tentativa do retorno da Igreja à pureza inicial. Todavia, ao contrário de Lutero que saiu em completa rutura, optou pela mudança no seio da própria Igreja.

A primeira reação às suas teses partiu dos Franciscanos e levou a Sorbonne a censurar as dezoito proposições que continham as inovações doutrinárias de ambos os teólogos. Baio reagiu mas Pio V impôs silêncio a ambas as partes sem, no entanto, se pronunciar sobre o seu conteúdo.

Em 1566, ano em que ocorreu a morte de Hessels, Baio reuniu todos os tratados de ambos na obra a que deu o título de Opuscula Omnia. No ano seguinte, com a data de 1 de maio, Pio V, através da Bula Ex Omnibus afflictionibus, condenou todas as suas proposições sem, no entanto, especificar nenhuma delas. Baio, após um período de incerteza, acabou por aceitar a bula papal, atitude que lhe valeu o

3 J.F. Sollier, Michel Baius, in Enciclopedia Católica online, traducido por Pedro Royo, Disponível em http://ec.aciprensa.com/wiki/MichelBaius. 
lugar de chanceler de Lovaina, deão da igreja colegiada de S. Pedro e conservador dos privilégios da Universidade. Baio atravessava, então, uma fase de grande fulgor que the incutiu a necessária confiança para retomar a divulgação das suas teses, ao ponto de se convencer que o novo papa, Gregório XIII, anularia as decisões condenatórias de Pio V. As suas expectativas goraram-se quando o Sumo Pontífice, pela bula Provisionis nostrae, se limitou a confirmar os actos do seu antecessor e a incumbir o teólogo jesuíta, de origem espanhola, Francisco de Toledo, de fazer entrega do documento a Baio e de receber dele a sua abjuração ${ }^{4}$. 0 visado submeteu-se à vontade de Gregório XIII e assinou um documento, intitulado Confessio Michaelis Baio, no qual declarava que "estou convencido de que a condenação de todas essas proposições é justa e legal" e, ainda, que "renuncio a todas elas e decido nunca mais ensinar ou defender nenhuma delas". Veio a falecer em Lovaina a 16 de setembro de 1589 .

Alguns anos mais tarde, Cornélio Jansénio ${ }^{5}$ vai aderir às teses doutrinais de Baio e interromper o período de paz vivido pela Igreja a partir do momento em que ocorreu a sua morte.

Jansénio nasceu em 1585 no seio de uma família católica, na cidade de Accoi, Leerdam, na Holanda. Após concluir os estudos superiores, ingressou no colégio Papa Adriano VI, presidido por Jacques Janson, fervoroso seguidor das teses de Baio. A sua influência contribuiu, de forma decisiva, para o rumo trilhado por Jansénio.

Em Lovaina conhecera Jean du Verger, um jovem, oriundo de famílias abastadas e poderosas, que, então, se encontrava no final do curso de Teologia, sob a direção dos Jesuítas, e que comungava, também, das mesmas ideias. Essa convergência de pensamento facilitou o estabelecimento de uma relação de amizade e de compromisso entre ambos.

Em 1606, Jean du Verger convenceu Jansénio a acompanhá-lo até Baiona, sua cidade natal, onde the conseguiu o cargo de diretor do colégio episcopal. Aí viveram cerca de onze anos, durante os quais aprofundaram o estudo dos Padres da Igreja, particularmente, de Santo Agostinho.

Em 1617, já regressado a Paris, Verger recebeu das mãos do Bispo de Poitiers a dignidade de Abade de San Cyran e Jansénio retornou a Lovaina para assumir a direção do recém-inaugurado colégio de Santa Pulquéria.

4 Jacob Schemutz, Baius (de Bay), Michel, disponível em

http://www.scholasticon.fr/Database/Scholastiques_fr.php?ID=194, consultado em 31/10/2015.

5 CATOLICISMO, A Pax Clementina - Episódio trágico da guerra entre a ortodoxia e o jansenismo no século XVII, Campos, RJ, fevereiro de 1953, $n^{\circ} 26$, pp. 5-6. 
Em 1619, depois de concluir o doutoramento em Teologia, foi-lhe confiada a cadeira de Exegese. Rapidamente conquistou a atenção dos seus alunos, o que tornou fácil a adesão destes à mensagem que pretendia transmitir-lhes.

Desenvolvia-se, então, naquela Universidade, já dominada pela fação jansenista, um conflito com o colégio dos Jesuítas. Jansénio recorreu a Filipe IV e conseguiu que este monarca retirasse aos Jesuítas o ensino de Humanidades e Filosofia.

Em 1636, graças ao excelente relacionamento com o mesmo monarca, Jansénio foi nomeado bispo de Ypres, dignidade que desempenhou com todo o zelo e fervor até 1638 , ano em que ocorreu o seu falecimento.

Dois anos depois, em 1640, os seus correligionários promoveram a publicação dos seus escritos, reunidos num só volume, intitulado Cornelli Jansenii, Episcopi Uprensis, Augustinus, seu doctrina de humanae naturae sanitate, medicina, adversus Plagius et Massiliense mas difundido apenas com designação de Augustinus.

A segunda página da obra insere uma declaração que constitui a expressão da sua última vontade e que não é mais que o reafirmar da sua fidelidade e sujeição à autoridade da Igreja: "Se, todavia, a Santa Sé deseja alguma mudança, eu sou um filho obediente e me submeto àquela Igreja na qual vivi até à hora da minha morte. Este é o meu último desejo".

Em Augustinus, em boa verdade, Jansénio, procurando escudar-se na doutrina de Santo Agostinho, deu guarida aos erros de Baio. E fê-lo porque estava convicto de que o recurso a tão insigne mestre reforçaria a força da sua argumentação contra as doutrinas expendidas pelos Jesuítas, em particular, por Luís de Molina.

Para Jansénio, como para Baio, a visão de Deus era, necessariamente, o fim da natureza humana. Dessa forma, o homem praticava o bem, influenciado pela graça e o mal, dominado pela cobiça. E, embora o fizesse voluntariamente, ele não tinha a capacidade para resistir nem a uma nem a outra. 0 homem, uma vez que foi contaminado por Adão, através do pecado original, era portador de uma natureza corrupta e depravada e apenas conseguia libertar-se da concupiscência se a força da graça lhe fosse superior.

Augustinus mereceu um acolhimento entusiasta e rapidamente se difundiu por países como a França, a Bélgica e a Holanda não obstante o anátema recebido de Roma que, sob a pressão dos Jesuítas de Lovaina, interditou, em 1641, a sua leitura, resolução confirmada por Urbano VIII quando, no ano seguinte, renovou a condenação e a sua proibição, através da bula In Eminenti. Todavia, o Sumo Pon- 
tífice, numa tentativa de instalar a paz, interditou, igualmente, a publicação de quaisquer escritos contra o Augustinus. ${ }^{6}$

Todas estas disposições impostas pela Igreja não arrefeceram o entusiamo despertado pela obra de Jansénio. Jean du Verger, Abade de San Cyran, intensificou a propagação das teorias desenvolvidas pelo seu amigo, sempre com o pretexto da necessidade de um retorno à pureza da Igreja primitiva.

Conseguiu arrastar para a sua causa a numerosa familia de Arnauld, designadamente António Arnauld e sua irmã, a Madre Angélica Arnauld, abadessa de Port-Royal, e uma boa parte das religiosas dessa celebrada abadia, situada no vale de Chevreuse, ao sul de Versailles. Após a morte do Abade de San Cyran, ocorrida em 1643, António Arnauld tomou sobre si a direcção do movimento jansenista, encontrando, então, um valioso aliado nas freiras cistercienses da abadia de Port-Royal, graças à interferência de sua irmã Angélica.

Em 1643, Arnauld fez publicar o livro que intitulou Sobre a comunhão frequente, um libelo contra a prática exagerada desse sacramento, posição adversa à preconizada pelos Jesuítas, os seus adversários mais ativos, que defendiam o oposto. 0 Parlamento de Paris, influenciado pelo escrito de Arnauld, aderiu ao movimento jansenista, atitude que agitou fortemente os opositores. A Santa Sé interveio de novo e Inocêncio X, através da Bula Cum ocasione, rejeitou, por heréticas, as proposições formuladas em Augustinus. Os jansenistas contestaram a sentença papal que, segundo o seu critério, confundia a doutrina apresentada em Agustinus com a preconizada por Calvino.

O diferendo prolongou-se e, em 1656, a Universidade de Sorbonne expulsou António Arnauld e mais sessenta outros professores que perfilhavam ideias idênticas. A tomada de tão radical posição por parte da Universidade levou Blaise Pascal, que, também ele, tinha uma irmã monja em Port-Royal, a juntar-se ao grupo e a colocar-se ao lado de Arnauld.

O seu livro, com o título de Cartas Provinciais, saído logo a seguir à sua adesão, e que representava um libelo contra a imoralidade da sociedade parisiense e contra a Companhia de Jesus, pelo laxismo dos seus membros, reforçou a posição do movimento jansenista.

Em 1660, Luís XIV tomou o partido dos Jesuítas e a posição dos jansenistas experimentou um assinalável enfraquecimento, facto agravado pela morte de Pascal, ocorrida em 1662.

6 Jansenio Y Jansenismo, disponível em http: //www.mercaba.org/Rialp/J/jansenio_y_jansenismo.htm, consultado em 31.10.2015. 
Em 1665, os bispos Henri Arnauld, de Angers, Buzenval, de Beauvais, Caulet de Parniers e Nicolas Pavillon, de Alet, publicaram uma pastoral em defesa da posição jansenista. A Santa Sé interveio, de novo, e o Papa Alexandre VII, respondeu com a bula Ad sanctam Beati Petri sedem, condenando os quatro prelados e impondo-lhes, ao mesmo tempo, a assinatura de um formulário no qual, cada um, deveria repudiar as cinco proposições, declaradas heréticas por Inocêncio X.

Decorridos dois anos, em janeiro de 1667, Roma criou uma comissão de nove bispos para proceder ao julgamento dos rebeldes. Entretanto, nesse mesmo ano, morreu Alexandre VII a quem sucedeu Clemente IX, que confirmou o poder dos juízes designados. Porém, o Sumo Pontífice, ante o receio do agravamento da relação com a Igreja francesa, recuou e contentou-se com a assinatura do formulário decidida pelos quatro Bispos. A atuação papal, que ficou conhecida pela Pax Clementina, acalmou os ânimos e satisfez a ambição dos jansenistas que lutavam arduamente para se manter dentro da Igreja.

Todavia, a submissão não impediu que a doutrina jansenista continuasse a difundir-se e a infiltrar-se, muito particularmente, no interior de diversas Ordens Religiosas.

No início do século XVIII, depois de um período de aparente tranquilidade, a polémica reacendeu-se quando foi colocada a questão de saber-se se podia ser absolvido um clérigo que observasse apenas um respeitoso silêncio (um silêncio obsequioso). Quarenta doutores da Sorbonne responderam afirmativamente. Roma saiu de novo à liça e, pela bula Viniam Domini Sabaoth, de 15 de julho de 1705, Clemente XI condenou a interpretação, no que foi acompanhado pelo arcebispo de Paris, Cardeal de Noailles, numerosos bispos, e pelas faculdades de Teologia de Lovaina, Dovai e Paris.

Os jansenistas não acataram, mais uma vez, a decisão papal e, em última instância, a Corte Francesa, com a concordância da Santa Sé, ordenou o fecho e a destruição dos edifícios da abadia e da própria igreja de Port-Royal. 0 símbolo do Jansenismo fora destruído e tudo parecia indiciar que, finalmente, a paz se instalaria definitivamente. Mas, não foi isso que se verificou. Paschier Quesnel (16341719), um ex-oratoriano, expulso pela sua simpatia pelas teses jansenistas e que se encontrava refugiado em Bruxelas, fez publicar o seu livro Reflexões Morais, que mereceu uma forte reação por parte dos Jesuítas. Clemente XI, mais uma vez instigado por estes, proibiu, em 1708, a leitura do livro sob pena de excomunhão, com o argumento de que o mesmo reincidia nos erros já condenados anteriormente. 
Com as medidas radicais adotadas por Roma e a morte de Quesnel, em 1719, o Jansenismo foi perdendo todo o seu vigor e acabou por desvanecer-se em França. Não pode deixar de ter-se em conta que a Igreja se encontrava envolvida noutras controvérsias preocupantes que absorviam toda a sua atenção. 0 procedimento da Igreja Francesa, que vinha colocando em causa o poder papal, com Luís XIV à cabeça, as doutrinas quietistas difundidas pelo movimento místico criado por Miguel de Molinos, as discussões em torno dos ritos chineses e malabares, contribuíram igualmente para o desvanecimento do conflito Jansenista.

\section{Jacobeia, a expressão do Jansenismo em Portugal}

Em Portugal, a Jacobeia, movimento religioso nascido da iniciativa de Francisco da Anunciação, no início do séc. XVIII, apresenta-se como o lídimo representante das doutrinas jansenistas. Começou por desenvolver-se nas comunidades dos eremitas de Santo Agostinho, em Coimbra, depressa se propagando a outras Ordens Religiosas, particularmente os Beneditinos, Carmelitas, Dominicanos e Cistercienses, e também granjeando aderentes nas mais altas esferas da hierarquia católica.

$\grave{A}$ imagem dos seus inspiradores, os Jacobeus tinham como fim essencial o combate ao laxismo que grassava na sociedade portuguesa, que atingira, no início do séc. XVIII, o mais baixo patamar da degradação, e o retorno do cristianismo à sua primitiva pureza. De nada valeu a tenaz repressão imposta pela Inquisição, como apropriadamente salienta Mário Rodrigues.

Chega-se a pasmar de que, apesar de tantas procissões, novenas, homílias, sermões, confissões; em despeito de tantos esbirros da Inquisição a farejar delitos por toda a parte e de tantos espiões do Santo Ofício introduzidos no seio das famílias, nos serviços públicos, nos serões pacatos; não obstante os exemplos dos autos de fé, dos pavorosos tormentos infligidos aos acusados das mais leves faltas, campeasse uma vaga de imoralidade tão infrene em todas as classes sociais, desde a realeza aos mais humildes servos ${ }^{7}$.

Os Jacobeus adotaram a teoria jansenista de que o homem, por si só, não tinha capacidade de salvação, necessitando, para tanto, da colaboração de Deus.

7 Rodrigues, Mário, O marquês de Pombal-O homem e a sua época, Lisboa, 1955, p. 13, apud Fr. António Pereira da Silva, A questão do Sigilismo em Portugal no Século 18, Braga [s.n.], 1964, p. 34. 
$\mathrm{Na}$ esteira dos grandes místicos espanhóis, como Santa Teresa d'Avila e S. João da Cruz, preconizavam a prática da oração mental, como uma das mais valiosas vias para alcançar a perfeição ${ }^{8}$.

De entre as figuras gradas integrantes do grupo jacobeu salientaram-se nomes como D. Fr. Miguel de Távora, futuro Arcebispo de Évora, Fr. Eugénio Trigueiros e Fr. José de Santa Maria, bem como Fr. Inácio de Santa Teresa, todos eremitas de Santo Agostinho. Os franciscanos aderiram ao movimento por iniciativa de Fr. António das Chagas, que organizou no Colégio do Varatojo a sua Jacobeia. Um dos nomes mais sonantes saídos da instituição foi o de Fr. Gaspar da Encarnação, doutor em Cânones pela Universidade de Coimbra, da qual seria depois reitor. Em 1723, o breve Ex iniuncto nobis, de Inocêncio XIII, nomeou-o visitador e reformador dos cónegos regrantes de Santa Cruz de Coimbra onde, por sua influência, as teses jacobeias foram efusivamente acolhidas. Anos mais tarde, em 1741, D. João $V$ integrou-o no seu Governo, facto que contribuiu para um inesperado reforço do grupo jacobeu?.

Vivia-se então a época de uma paixão obsessiva por freiras, cultivada pelos chamados freiráticos, saídos da burguesia, do clero e da própria Corte. Fr. Gaspar da Encarnação, valendo-se do alto posto que ocupava, iniciou uma perseguição atroz contra essa espécie de gente, prendendo muitos e desterrando outros. Tudo isto, sob o beneplácito do rei, ele próprio pertencente ao grupo, porque mantinha ligação com uma freira de Odivelas que visitava assiduamente sem qualquer dissimulação ${ }^{10}$.

As normas de conduta postas em prática e divulgadas pelos jacobeus colidiam com a consciência de um vasto setor da sociedade, encabeçada por uma ampla camada do clero, que se servia de todos os processos para manifestar-lhes uma feroz animosidade, incidindo, particularmente, sobre os líderes do movimento reformador e que provinha, não raras vezes, de religiosos da mesma congregação. Todavia, não se revelaram muito rendíveis os frutos das campanhas empreendidas contra as práticas jacobeias até ao momento em que foi lançada sobre os confessores aderentes, designadamente, os missionários franciscanos do Colégio do Varatojo, a acusação de violarem o segredo da confissão, com a permissão dos seus superiores. E essa acusação assumia uma maior gravidade quando se acrescentava que os

8 Émile Appolis, Mystiques portugais du XVIII siècle: jacobéens et sigillistes In: Annales. Économies, Sociétés, Civilisations. 19 e année, N. 1, 1964, p. 39.

9 Ibidem, p. 40.

10 Émile Appolis, op. cit., p. 41. 
confessores, utilizando as palavras da pastoral do cardeal-patriarca de Lisboa, de 3 de maio de $1745^{11}$,

“[...] obrigáram aos penitentes a manifestar o cumplice do seu peccado, e a que lhes déssem licença, com pena de lhes negarem a absolvição, para usarem daquella noticia em ordem á emenda dos delictos communs."

Em 1745, o litígio entre os jacobeus e os seus opositores atingiu o ponto culminante. Com efeito, D. Tomás de Almeida, o cardeal-patriarca de Lisboa e D. Nuno da Cunha, acolhendo as constantes denúncias provindas, maioritariamente, dos setores freiráticos, os mais incomodados com as teorias jacobeias e as vítimas principais da sua vindicta, insurgitam-se contra os jacobeus, acusados de sigilistas, fazendo publicar, o primeiro, a pastoral de 3 de maio, e o segundo, o edital de 6 do mesmo mês. 0 cardeal aconselhava os confessores a não investigarem mais que o necessário para o correto conhecimento da gravidade das culpas, devendo coibir-se de usarem as informações obtidas na confissão para quaisquer outros fins e, muito menos, de forçarem os penitentes à delação dos seus cúmplices, sob pena de suspensão ipso facto, não o fazendo ${ }^{12}$.

Por sua vez, o inquisidor-mor cominava, com a pena de excomunhão maior, todos os confessores que recorressem a tal prática. Porém, mais grave que isso, instigava os penitentes à denúncia dos prevaricadores, na Mesa do Santo Ofício, que incorreriam na mesma pena se o não fizessem. Com idêntica cominação, ordenava a todos os abades, priores, reitores, vigários, curas e prelados dos conventos do reino e também aos senhorios a leitura e a afixação do edital.

Iniciava-se, a partir daqui, um dos mais graves conflitos desenvolvidos no seio da Igreja portuguesa, que ficou conhecido pela Questão do Sigilismo, tendo como litigantes, de um lado, o patriarca de Lisboa e o inquisidor-mor do Santo Ofício, e do outro, uma porção considerável de bispos e arcebispos portugueses Jacobeus,liderados, sem surpresa, por D. Miguel da Anunciação, bispo de Coimbra, D. Miguel de Távora, arcebispo de Évora, e D. Inácio de Santa Teresa, arcebispo-bispo do Algarve. Somente em 1949, a Bula de Bento XIV, Apostolici Ministeri, de 9 de setembro ${ }^{13}$, veio trazer algum paz. Com ela, o Papa deixou na mão do Santo Ofí-

11 José de Seabra da Silva, Memorial sobre o scisma do sigillismo que os denominados Jacobeus e Beatos levantaram neste Reino de Portugal l...], Lisboa, na Regia Off. Typográfica, 1769, p. 81.

12 Ibidem.

13 Everton Sales de Souza, Jansénisme et Reforme de l'Église dans l'empire portugais, Paris, Centre Culturel Calouste Gulbenkian, 2004, p. 220. 
cio, quase que em exclusivo, a competência para decidir sobre os delitos desta natureza. Os ânimos aquietaram-se e confronto entre os dois grupos acabou por desvanecer-se.

Cerca de vinte anos depois, com o Marquês de Pombal no poder, a questão Jacobeia, que antes não saíra do foro teológico, reacendeu-se mas com um cunho marcadamente político. Os objetivos já não eram os mesmos. Nicolas Hernan Perrone, referindo-se às diferenças entre o Jansenismos dos séculos XVII e XVIII, observa que

Mientras que en el siglo anterior (Sec. XVII), las disputas se efectuaban sobre todo en el campo soteriológico, el jansenismo dieciochesco, luego de la "derrota" de la bula Unigenitus, estuvo imbuido sobre todo de un particular espirito galicano-regalista y de acentuados rasgos moralistas ${ }^{14}$.

Efetivamente , Pombal assumiu a conceção de poder decretada, em 1663, pela Sorbonne, ao rejeitar a autoridade de Roma em relação ao poder real. ${ }^{15}$ Dentro desse contexto, o poder temporal concentrava-se em exclusivo no Rei e o Papa quedava-se tão só com o poder espiritual. Eram os efeitos de uma nova época marcada pelo iluminismo.

Na definição de Zita Osório de Castro, “[...] o pombalismo, na sua política regalista, pretendia a sua exaltação mediante a afirmação e consolidação da sua plena jurisdição temporal”'16.

A conduta do ministro português parece até ter sido, de início, benevolente para os Jacobeus, tal como aconteceu, de resto, em relação aos Jesuítas. Mas, em 1768, a fúria de Pombal atinge os Jacobeus, na pessoa de D. Miguel da Anunciação, com um duro golpe, justificado pela sua fidelidade à Santa Sé .

Emile Apolis acrescenta uma outra razão, ao considerar a ação de Pombal como um acto de revanchismo contra a família dos Távoras, da qual o Bispo era um dos membros, pelo facto de se considerar vexado pelo bispo do Porto, D. António de Sousa, anos atrás.

14 Nicolas Hernan Perronne, “Si no eres Jesuita serás Jansenista, Y si no eres Jansenista serás Jesuita”. El problema del Jansenismo en causas de la Revolucion de Francia, de Lorenzo Hervás Y Panduro S.J. (1735-1809)

In Hispania Sacra, LXV Extra II, julio-diciembre 2013, pp. 203-230, disponível em . http://hispaniasacra.revistas.csic. es/index.php/hispaniasacra/article/view/372.

15 Galicanismo, Enciclopédia Católica, disponível em http://ec.aciprensa.com/wiki/Galicanismo.

16 Zília Osório de Castro, Sob o signo da unidade. Regalismo vs. Jesuitismo, Brotéria, vol. 169, Agosto/Setembro 2009, p. 121. 
Le nouveau ministre semble d'abord en bons termes avec la secte. C'est lui qui, en 1756, nomme Antonio de Sousa à l'évêché de Porto, à la suite de la conduite héroïque qu'il a eu lors du tremblement de terre de Lisbonne, le 1er novembre 1755. Mais l'intrigant ministre souhaiterait marier son fils aîné avec une jeune fille de la maison de Tavora, «une des plus illustres, et sans contredit la plus ancienne du Royaume ». Il s'en ouvre au prélat, «que son grand âge et sa prudence consommée font respecter de toute sa famille». - Combien je m'estimerais heureux, lui déclare-t-il, si le Marquis Dom François voulait donner pour épouse à mon fils une de ses filles.» Surpris de cette confidence, l'évêque ne peut s'empêcher de répondre : - Votre Excellence porte ses vues bien haut ! »17

A conceção regalista ${ }^{18}$ do ministro foi, decididamente, rejeitada por D. Miguel da Anunciação, que se opunha à supremacia do poder civil.

Em 8 de dezembro de 1768, o Prelado emitiu uma pastoral na qual alertava para a proliferação de livros que considerava heréticos por ofenderem doutrinas reprovadas pela Igreja, de entre os quais se salientavam as obras de Voltaire e de Rousseau.

Nesse mesmo dia, Pombal, insurgindo-se violentamente contra o teor da pastoral, ordenou a prisão de D. Miguel da Anunciação e a sua destituição do cargo ${ }^{19}$, remetido depois a Lisboa sob uma numerosa escolta e encerrado nos calabouços do forte de Pedrouços. O mesmo destino caíu sobre o seu secretário e todos os seus colaboradores, não excluindo sequer os próprios serviçais domésticos ${ }^{20}$.

O revanchismo estendeu-se à Universidade de Coimbra, com a expulsão de todos os Jacobeus, considerados inaptos para qualquer função, tendo muitos deles acabado por encher as prisões do Santo Ofício ${ }^{21}$.

No edital do Conselho Geral do Santo Ofício, de 24 de julho de 1769, a Real Meza Censória zurzia com violência os sigilistas, jacobeus e beatos, "seita ordenada a se poderem sacrilegamente servir do Sigillo da Confissão para os temporaes, e reprovados fins dos seus interesses económicos, e políticos, ou das suas vinganças [...]”22.

17 Emile Appolis, op. cit., p.47.

18 Regalismo, um sistema que preconizava a intromissão do poder civil ou da Coroa no governo da Igreja.

19 Edital de 9 de Dezembro de 1768, apud Manuel Augusto Rodrigues, D. Miguel da Anunciação e o Cabido da Sé de Coimbra, Separata do Boletim do Arquivo da Universidade de Coimbra, vol. V, p. 251.

20 Émile Appolis, op. cit., p. 49.

21 Manuel Augusto Rodrigues, op. cit., p. 236.

22 Colecção Terceira que comprehende a Bulla Ubi Primum do Santissimo P.e Benedicto XIV, Nosso Senhor, Madrid, En la Officina de Antonio Sanz, Año de 1746, p. 243. 
Acusava-os de seguirem "as pestilenciaes doutrinas dos pertendidos Jesuitas, e de outros homens de corrompidas consciências" e ordenava a entrega ao tribunal de todas as obras, livros e papeis por eles publicados, proibindo a sua venda e distribuição.

D. Miguel da Anunciação permaneceu detido durante mais de oito anos. Somente a 21 de fevereiro de 1777, foi agraciado por D. José, justamente três dias antes do seu falecimento. Revela Emile Appolis que a prisão onde o Arcebispo se encontrava detido apenas foi identificada após interrogatório do próprio Pombal .

Reabilitado por D. Maria I, D. Miguel da Anunciação reocupou, em triunfo, a 22 de agosto seguinte, a sua cadeira episcopal. No final do ano, durante a visita pastoral que empreendeu na sua diocese, ele encontra-se com o Marquês, caído em desgraça, que the manifestou o seu arrependimento pela crueldade do tratamento que the havia infligido.

\section{Inácio de Santa Teresa e a Jacobeia}

Não surpreendeu a adesão de D. Inácio de Santa Teresa, também ele um cónego regrante de Santa Cruz, a esse movimento. Pouco tempo depois de chegar a Goa, embrenhou-se num confronto com os Jesuítas que o vão acusar de práticas heréticas, conotadas com o Jansenismo, dando origem à instauração de um processo pela Inquisição local.

A visita que, pouco depois de iniciar funções, empreendeu às igrejas de Salcete provocou a saída de todos os párocos jesuítas em protesto contra algumas iniciativas por ele tomadas, que punham em causa a honorabilidade de alguns desses párocos. Estabeleceu-se uma guerrilha institucional entre D. Inácio de Santa Teresa e apaniguados, de um lado, e as Congregações Religiosas, do outro, que duraria enquanto o Prelado se manteve em Goa. As posições de cada uma das partes extremaram-se de tal modo que qualquer pretexto constituía argumento válido para novas agressões.

No decorrer de um sermão proferido durante a Quaresma de 1725, o Arcebispo terá afirmado que "as boas obras feitas em peccado, ainda que em si boas, são abominação para Deos por razão do sujeito" 23 proposição que, no entanto, os seus adversários asseveravam ter sido, textualmente, a de que "todas as obras boas feitas pelos que estão em peccado erão abominações".

23 Biblioteca Nacional de Portugal, cod. 1522, Censura Verdadeira de huma falsa e caviloso censura [...], p. 155. 
Os Jesuítas terão tomado conhecimento da proposição através do governador Cristóvão de Mello que se encontrava na catedral quando D. Inácio de Santa Teresa proferiu o seu sermão ${ }^{24}$. 0 episódio foi o ponto de partida para um novo pleito de cariz teológico, envolvendo o Arcebispo e os seus inimigos Jesuítas que o vão acusar de práticas jansenistas.

$\mathrm{Na}$ audição que the foi feita no Tribunal do S. Ofício, o denunciado procurou esclarecer o teor das afirmações que havia proferido, o que, todavia, não impediu o prosseguimento do processo não só naquele Tribunal como também no de Lisboa. E, na verdade, a partir desse momento, o Pe. Manuel de Sá, uma espécie de porta-voz da Companhia de Jesus, não mais parou de fustigar o Arcebispo com inflamados folhetos, anónimos ou subscritos sob o pseudónimo de Fr. Veríssimo da Piedade, nos quais se esforçava por demonstrar que ele havia recuperado as teses de Miguel Baio, que entendia que tudo o que o pecador ou o escravo faziam era pecado. Conotava-o, também, com Plágio ${ }^{25}$, segundo o qual as obras feitas fora da graça da adoção não eram meritórias para o reino dos céus, doutrina que havia sido condenada por Pio V, através da bula Ex omnibus afflictionibus, de 1 de outubro de 1567, e, mais tarde, por Gregório XIII, com a bula Proposionis nostrae ${ }^{26}$, de 29 de janeiro de 1580. Nomeadamente, no seu escrito Verdades catholicas contra axiomas heréticos ${ }^{27}$, ele procurou estabelecer uma relação entre algumas das ações do Arcebispo e as práticas jansenistas, numa clara tentativa de o incluir no rol de hereges que procuravam minar os alicerces da Igreja e escandalizar os seus fieis.

Não obstante a reiterada negação dos fatos de que era acusado, o Tribunal da Inquisição aceitou a denúncia e procedeu à instrução do correspondente processo. Dada a sua especial natureza, o cardeal Nuno da Cunha, inquisidor-mor, chamou a si a sua coordenação ${ }^{28}$. Foram repetidas as tentativas que fez junto do Arcebispo para que se retratasse, argumentando sempre com os supremos interesses da Igreja. O Arcebispo mostrou-se insensível a todos os argumentos aduzidos pelo seu antagonista e manteve-se fiel aos seus princípios. Continuava a sustentar que fora acusado de uma falta que não cometera porque a proposição proferida e que the imputara o Pe. Manoel de Sá, fora falseada, viciada e falsificada com três mutilações. Que aquela que proferira se continha na Sagrada Escritura. E acrescentava

24 Idem, cod. 1521.

25 Plágio foi um monge, nascido na Bretanha, que discutiu com Santo Agostinho, menosprezando o papel da graça divina em detrimento da eficácia do esforço de cada indivíduo.

26 Compendio de símbolos, definições e declarações de fé e moral, H. Denzinger, trad. De José Mariano e Johan Konings, S. Paulo, Paulinas, Edições Loyola, pp. 468, 470 e 473.

27 Biblioteca Pública de Évora, cod. CX/1-6, $\mathrm{n}^{\circ}$. 11, Verdades catholicas contra axiomas heréticos.

28 Biblioteca Nacional de Portugal, cod. 1521 
que uma vez que o negócio havia já sido afecto à Sagrada Congregação, conformar-se-ia com o que a mesma finalmente decidisse. 0 inquisidor-mor fez uma última tentativa, em carta de 2 de abril de 1732, no sentido de demover o Arcebispo, reiterando o pedido de que se desdissesse por a sua proposição haver sido qualificada por muitos nomes doutos, quer vivos quer já falecidos. Todavia, nada fez demover o Arcebispo. E a razão estava do seu lado, como veio a entendê-lo a Sagrada Congregação do Santo Ofício cujo parecer Clemente XII acolheu. De facto, em 1737, a 15 de agosto, pondo fim a um longo processo de 12 anos, o Sumo Pontífice, pelo breve Inter Luculenta Laboris Solatia, declarava que as proposições de D. Inácio de Santa Teresa se achavam conformes com a doutrina reconhecida pela Igreja e não mereciam qualquer censura ${ }^{29}$.

\section{Bibliografia}

Emile Appolis, Mystiques portugais du XVIIle siècle : jacobéens et sigillistes In: Annales. Économies, Sociétés, Civilisations. 19e année, N. 1, 1964. pp. 38-54.

Biblioteca Nacional de Portugal, cods. 1521 e 1522 (Censura Verdadeira de huma falsa e caviloso censura $[\ldots])$.

Biblioteca Pública de Évora, cod. CX/1-6, nº.11, Verdades catholicas contra axiomas heréticos.

Castro, Zília Osório de, Sob o signo da unidade. Regalismo vs. Jesuitismo, Brotéria, vol. 169, Agosto/Setembro 2009, pp. 113-134.

Catolicismo, A Pax Clementina - Episódio trágico da guerra entre a ortodoxia e o jansenismo no século XVII, Campos, RJ, fevereiro de 1953, nº 26.

Compendio de simbolos, definições e declarações de fé e moral, H. Denzinger, trad. de José Mariano e Johan Konings, S. Paulo, Paulinas, Edições Loyola.

D. Pizzinga, Pensamentos de Lutero, Um revolucionário religioso, disponível em http:// ordoilluminatorum.net/.

J.F. Sollier, Michel Baius, in Enciclopedia Católica online, Traducido por Pedro Royo, disponível em http://ec.aciprensa.com/wiki/MichelBaius.

Jacob Schemutz, Baius (de Bay), Michel, disponivel em http://www.scholasticon.fr/Database/Scholastiques_fr.php?ID=194.

29 Ibidem. 
Jansenio Y Jansenismo, disponível em http://www.mercaba.org/Rialp/J/jansenio_y_jansenismo.htm.

Oliveira, Miguel, História Eclesiástica de Portugal, 1994, Lisboa, Publicações Europa América.

Perrone, Nicolas Hernán, "Si no eres jesuita serás jansenista; y si no eres jansenista serás jesuita. El problema del jansenismo en causas de la revolución de Francia de Lorenzo Hervás Y Panduros S.J. (1735-1809)", Hispania Sacra, LXV Extra II, julio-diciembre 2013, pp. 203-230, disponível em https://dialnet.unirioja.es/servlet/articulo?codigo $=4603954$.

Rodrigues, Manuel Augusto, D. Miguel da Anunciação e o Cabido da Sé de Coimbra, separata do Boletim do Arquivo da Universidade de Coimbra, vol. V.

Santos, Cândido dos, História do Jansenismo em Portugal, 2007, Porto, Faculdade de Letras da Universidade do Porto.

Silva, Fr. António Pereira da, A questão do sigilismo em Portugal no século XVIII: história, religião e política nos reinados de Dom João V e de Dom José I, 1964, Braga.

Sousa, Everton Sales, Jansénisme et Reforme de l'Église dans l'empire portugais, Paris, Centre Culturel Calouste Gulbenkian, 2004. 